NBSIR 76-1066

\title{
Center for Consumer Product Technology Publications, November 1974 to April 1976
}

Suellen Halpin

Center for Consumer Product Technology Institute for Applied Technology National Bureau of Standards

Washington, D. C. 20234

June 1976

Final

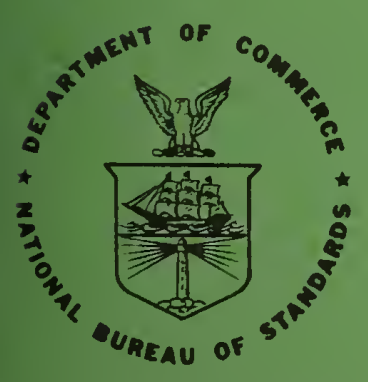

U. S. DEPARTMENT OF COMMERCE 

NBSIR 76-1066

CENTER FOR CONSUMER PRODUCT

TECHNOLOGY PUBLICATIONS,

NOVEMBER 1974 TO APRIL 1976

Suellen Halpin

Center for Consumer Product Technology

Institute for Applied Technology

National Bureau of Standards

Washington, D. C. 20234

June 1976

Final

U.S. DEPARTMENT OF COMMERCE, Elliot L. Richardson, Secretary

Dr. Betoy Ancker-Johnson. Assistant Secretary for Scienco and Tochnology

NATIONAL BUREAU OF STANDARDS, Emeet Ambler. Acting Director 

Table of Contents

I. National Bureau of Standards Interagency Reports

II. National Bureau of Standards Technical Notes

III. National Bureau of Standards Law Enforcement Standards Program Reports

IV. National Bureau of Standards Law Enforcement Equipment Standards

V. National Bureau of Standards Law Enforcement Equipment Guidelines

VI. Contract Reports

VII. Federal Register Documents

VIII. Papers Presented

IX. Other Agency Reports 
"Center for Consumer Product Technology Publications, November 1974 to April 1976" lists only publications prepared by the members of the Center for Consumer Product Technology (CCPT) staff, by National Bureau of Standards (NBS) personnel under contract or grant to the CCPT, or by NBS personnel or external laboratories under contract or grant from the CCPT are cited. Articles published in NBS house publications also are cited. 
I. NATIONAL BUREAU OF STANDARDS INTERAGENCY REPORTS

NBSIR 74-546 Maness, J. E., A Synthetic Material for Detecting Hazardous Edges, January 1975.

NBSIR 74-590 Toner, S. D., A Study of the Feasibility of Establishing Generic Environmental Test Parameters for All Consumer Products, March 1975.

NBSIR 74-621 Mahajan, B. M., Stability and Strength of Home Playground Equipment, January 1975.

NBSIR 74-623 Brown, W. C., and H. A. Baker, Stability and Abuse Tests of Riding Toys, January 1975.

NBSIR 75-651 Stiefel, S. W. , C. W. Hand, and D. W. Corrigan, Procedural Options to Reduce the Risk of Injury from Products Installed in Residences, June 1975.

NBSIR 75-660 McGuire, B. J., and E. A. Vadelund, Voluntary Labeling Program for Household Appliances and Equipment to Effect Energy Conservation: Annual Report for Calendar Year 1975, February 1975.

NBSIR 75-677 Bunten, E. D., J. L. Donaldson and E. C. McDowe11, Hazard Assessment of Aluminum Electrical Wiring in Residential Use, December 1974.

NBSIR 75-707 Laug, O. B., and K. W. Yee, Tamper-Resistant Television Surveillance System, May 1975.

NBSIR 75-714 Pierson, R., R. I. Beal1, and J. A. Huckeba, Report of Test on a Sample of Non-Standard Size Baby Cribs, May 1975.

NBSIR 75-719 Report on a Compliance Testing System for NILECJ

NBSIR 75-722 Morse, M. S., Closure Testing Equipment Instruction Manual, October 1975.

NBSIR 75-733 Toner, S. D., and H. A. Baker, An Evaluation of Proposed Safety Requirements for Infant Pacifiers, August 1975.

NBSIR 75-734 Collard, J. J., Report on an Investigation of the High Speed Hazards of Steel Belted Radial Tires on Patrol Cars, June 1975.

NBSIR 75-746 Greenough, M. L., and R. M. McCabe, Preparation of Reference Data Sets for Character Recognition Research, August 1975. 
NBSIR 75-748 Pezoldt, V. J. and J. J. Persensky, Power Saws: A Review of Injury Data and Power Saw Industry Survey, July 1975.

NBSIR 75-758 Stokesberry, D. 1'., and S. Ilasegawa, Operation Manua1 for Microwave llygrometer Model III, August 1975.

NBSIR 75-797 Stef1, M. E., and J. J. Persensky, An Lvaluation of a Range-Top Warning Light System, July 1975.

NBSIR 75-813 Jones, R. N., Electronic Lavesdropping Techniques and Equipment, June 1975.

NBSIR 75-908 Cohen, J., Characterization of Sharp Points and Ldges by Electrical Breakdown, October 1975.

NBSIR 75-954 Goodman, P. C., A Survey of Manufacturers' Views on the ETIP Procurement Experiment, Volume One:

Refrigerators-Freezers, December 1975.

NBSIR 75-969 Stef1, M. E., P. C. Goodman, A. N. Ramey, and F. D. Bents, Accidents Involving Several Selected Appliances: Summary and Descriptive Analysis, December 1975.

NBSIR 76-983 Goodman, P. C., A Survey of Manufacturers' Views on the ETIP Procurement Experiment, Volume Two: Water Heaters, January 1976.

NBSIR 76-1007 Meguire, P. G., and J. J. Kramer, Psychological Deterrents to Nuclear Theft: A Preliminary Literature Review and Bibliography, March 1976.

II. NATIONAL BUREAU OF STANDARDS TECHNICAL NOTES

TN 859 Kapsch, R., and J. Stroik, Editors, Literature Search: Law Enforcement Facilities - Planning, Design Construction, November 1975.

III. NATIONAL BUREAU OF STANDARDS LAW ENFORCEMENT STANDARDS PROGRAM REPORTS LESP-RPT-0101.01 Dobbyn, R. C., W. J. Bruchey, and L. D. Shubin, An Evaluation of Police Handgun Ammunition: Summary Report, August 1975.

LESP-RPT-0209.00 Report on Tests of Digital Data Transmission on Voice Channels.

LESP-RPT-0306.00 Report on Terms and Definitions for Door and Window Security. 
LESP-RPT-0307.00 Grover, C., Photographic Terms and Definitions, October 1975.

LESP-RPT-0308.00 Catalog of Security Equipment

LESP-RPT-0309.00 Fechter, J. E. and E. Robertson, Directory of Security Consultants, October 1975.

LESP-RPT-0310.00 Report on a Simple Method for Evaluating the Spectral Responsivity of Monochrome Television Cameras.

LESP-RPT-0402.00 Report in the Police Patro1 Car: Economic Efficiency in Acquisition, Operation and Disposition.

LESP-RPT-0403.00 Massey, R. G., The Police Patrol Car: State of the Art, July 1975.

LESP-RPT-0404.00 Report on an Investigation of the High Speed Hazards of Steel-Belted Radial Tires on Police Patrol Cars.

LESP-RPT-0601.00 Steinberg, H. L., Standard Reference Collections of Forensic Science Materials: Status and Needs, September 1975.

LESP-RPT-0602.00 Report on the Hazard of Benzidine to Criminal Justice Personnel.

LESP-RPT-0604.00 Report on a Trace Vapor Generator for Testing Explosives Vapor Detectors.

LESP-RPT-0605.00 Report on the Characterization of Auto Headlight Glass by Refractive Index and Density.

LESP-RPT-0606.00 Report on an Assessment of Gunshot Residue Detection Using Neutron Activator Analysis, April 1976.

LESP-RPT-0701.00 Anthropometry of Law Enforcement Officers .

IV. NATIONAL BUREAU OF STANDARDS LAW ENFORCEMENT EQUIPMENT STANDARDS

NILECJ-STD-101.00 Guide to Hearing Protectors for Use on Firing Ranges, March 1975.

NILECJ-STD-0105.00 Crash Helmets, June 1975.

NILECJ-STD-0160.00 Ballistic Helmets, March 1975. 
NILECJ-STD-0206.00 Fixed and Base Station FM Receivers, September 1975.

NILECJ-STD-0207.00 Mobile FM Receivers, June 1975.

NILECJ-STD-0208.00 Personal/Portable FM Receivers, September 1975.

NILECJ-STD-0211.00 Batteries for Persona1/Portable Transceivers, September 1975.

NILECJ-STD-0212.00 RF Coaxial Cable Assemblies for Mobile Transceivers, September 1975.

NILECJ-STD-0304.00 Passive, First Generation Night Vision Devices, June 1975.

NILECJ-STD-0305.00 Active Night Vision Devices, June 1975.

NILECJ-STD-0306.00 Physical Security of Door Assemblies and Components, December 1975.

NILECJ-STD-0308.00 Standard for Sound Sensing Burglar Alarms:

NILECJ-STD-0309.00 Standard for U1trasonic Motion Detectors for Burglar Alarm Systems.

NILECJ-STD-0310.00 Standard for Microwave Motion Detectors for Burglar Alarm Systems.

NILECJ-STD-0311.00 Standard for Microphone Vibration Sensing Burglar Alarms.

NILECJ-STD-0312.00 Standard for Mechanical Contact Vibration Sensors for Burglar Alarm Systems, April 1976.

NILECJ-STD-0314.00 Standard for Infrared Photoelectric Burglar Alarm Systems.

NILECJ-STD-0501.00 Standard for Emergency Vehicle Sirens.

NILECJ-STD-0603.00 X-Ray Systems for Bomb Disarmament, May 1975.

NILECJ-STD-0604.00 Standard for Chemical Spot Test Kits for Preliminary Identification of Drugs and Abuse.

V. NATIONAL BUREAU OF STANDARDS LAW ENFORCEMENT EQUIPMENT GUIDELINES NILECJ-GUIDE-0201.00 Guide to Voice Scramblers for Law Enforcement Agencies.

NILECJ-GUIDE-0301.00 Selection and Application Guide to Fixed Surveillance Cameras, December 1974. 
NILECJ-GUIDE-0303.00 Guide to Police Photographic Equipment.

NILECJ-GUIDE-0501.00 Guide to Warning Lights and Sirens for Emergency and Service Vehicles.

VI. CONTRACT REPORTS

Human Sciences Research, Inc.

Brown, G. L., R. L. Hiett, and M. D. Havron, A Study to Evaluate NBS-Developed Labels for Water Heaters, HSR-RR-75/7-Sy, NBS-PO-512265, June 1975.

Hiett, R. L., G. L. Brown and R. L. Blanton, Methodology for

Evaluating the Impact of the Department of Commerce Voluntary Labeling Program for Home Appliances, HSR-RR-75/9-Ce, NBS Contract No. 5-35897, November 1975.

VII. FEDERAL REGISTER DOCUMENTS

40FR8816 Efficiency Program: announcement, March 3, 1975.

40FR14961 Labeling Program: annual report announcement, Apri1 3, 1975.

40FR23914 Proposed Efficiency Program: room air conditioners, June 3, 1975.

40FR26287 Proposed Efficiency Program: freezers, June 23, 1975.

40FR26290 Proposed Efficiency Program: gas water heaters, June 23, 1975.

40FR26294 Proposed Efficiency Program: electric water heaters, June 23, 1975.

40FR26298 Proposed Efficiency Program: refrigerators and refrigerator-freezers, June 23, 1975.

40FR28650 Proposed Efficiency Program: color television receivers, July 8, 1975.

40FR28653 Proposed Efficiency Program: monochrome television receivers, July 8, 1975.

40FR28832 Proposed Efficiency Program: electric clothes dryers, July 9, 1975. 
40FR28835 Proposed Efficiency Program: electric ranges, July 9, 1975 .

Proposed Efficiency Program: gas clothes dryers, July 9, 1975.

40FR29103 Proposed Efficiency Program: clothes washers, July 10, 1975.

40FR29106 Proposed Efficiency Program: dishwashers, July 10, 1975.

40FR29109 Proposed Efficiency Program: gas ranges, July 10, 1975.

40FR32415 Final Labeling Specifications: refrigerators, refrigerator-freezers, and freezers, August 1, 1975.

40FR34172 Proposed Labeling Specification: water heaters, August 14, 1975.

40FR57819 Proposed Labeling Specification: clothes dryers, December 12, 1975.

VIII. PAPERS PRESENTED

Stiefel, S. W., "Procedural Options for Modification of Architectural Glass in Residences to Improve Occupant Safety," Proceedings of 24th Annual Conference, Standard Engineers Society, September 28, to October 1, 1975.

McGuire, B. J., "The Department of Commerce Energy Labeling and Energy Efficiency Programs for Household Appliances," Proceedings of National Agricultural Outlook Conference, U.S. Department of Agriculture, November 17 to 20, 1975. Published: December 18, 1975, Committee on Agriculture and Forestry, U. S. Senate.

IX. OTHER AGENCY REPORTS

FHWA-RD-75-118 Fechter, J. V., V. J. Pezoldt, J. J. Persensky, and J. R. Lepkowski, Study of the National Standards for Directional and other Official Signs: Overview of Their Adequacy, prepared for the Federal Highway Administration, Department of Transportation, NBS PO-5-3-0148, October 1975.

X. ADDITIONAL READINGS

"Are 'Portable' Consumer Products Really Portable," NBS Standard 21, 2 (1976), p. 4.

"Check Energy Labels on Room Air Conditioner," Dimensions 59, 6 (1975), p. 138.

Collard, J. J., "Patrol Car Performance and Safety Studied," Dimensions 59, 3 (1975), p. 63. 
"Consumers Sound Off," NBS Standard 20, 12 (1975), p. 3.

"Crime Labs Aided by NBS Glass Standards," Dimensions 59, 1 (1975), p. 8 .

Dobbyn, R. C., "Helping Improve Police Protection," Dimensions 59, 3 (1975), p. 58.

Eliason, L. K., "Investigating the Performance of Security Systems," Dimensions 59,3 (1975), p. 60 .

"Energy Efficient Water Heaters to Save Money," Dimensions 59, 8 (1975), p. 189.

"Energy Labeling Explained for Consumers," Dimensions 59, 9 (1975), p. 210 .

Falge, R. L., "Guidelines for Keeping Better Court Records," Dimensions 59, 3 (1975), p. 56.

"Fifty-Seven Major Appliance Manufacturers Support Energy Efficiency Program," Dimensions 59, 11 (1975), p. 257.

"Law Enforcement Standards Laboratory," Dimensions 59,3 (1975), p. 51 .

"Major Appliance Manufacturers Support Energy Efficiency Program," Dimensions 59, 6 (1975), p. 137.

"Major Firms for Energy Savings," NBS Standard 2, 19 (1975), p. 1.

Mil1s, R. M., "Toward More Objective Evidence: Support for Forensic Science at NBS," Dimensions 59, 3 (1975), p. 59.

"More Energy Efforts," NBS Standard 20, 3 (1975), p. 1.

"NBS Strengthens Consumer Programs," Dimensions 59, 1 (1975), p. 20.

"NBS Tests 'Little Box' That Speeds Police Communications," Dimensions 59,5 (1975), p. 115.

"New Air Conditioners Save Energy, Money," Dimensions 59, 7 (1975), p. 164.

"New Strength for Product Research," NBS Standard 19, 26 (1974), p. 1 .

"Now Hear This! Protect Your Ears or Don't Shoot," Dimensions 59, 10 (1975), p. 219. 
"Safety of Playground Equipment," Dimensions 59, 2 (1975), p. 36 to 38 .

"Someone's in the Kitchen," NBS Standard 21, 6 (1976), p. 4. "Standard Issued for Police Portable Transceiver Batteries ," Dimensions 60, 3 (1976), p. 20.

"Surveillance Camera Guideline to Help Cut Thefts," Dimensions 59, 5 (1975), p. 114 .

Treado, M., "Safer Streets Through Improved Communication," Dimensions 59,3 (1975), p. 54. 
NBS-114A (REV. 7.73)

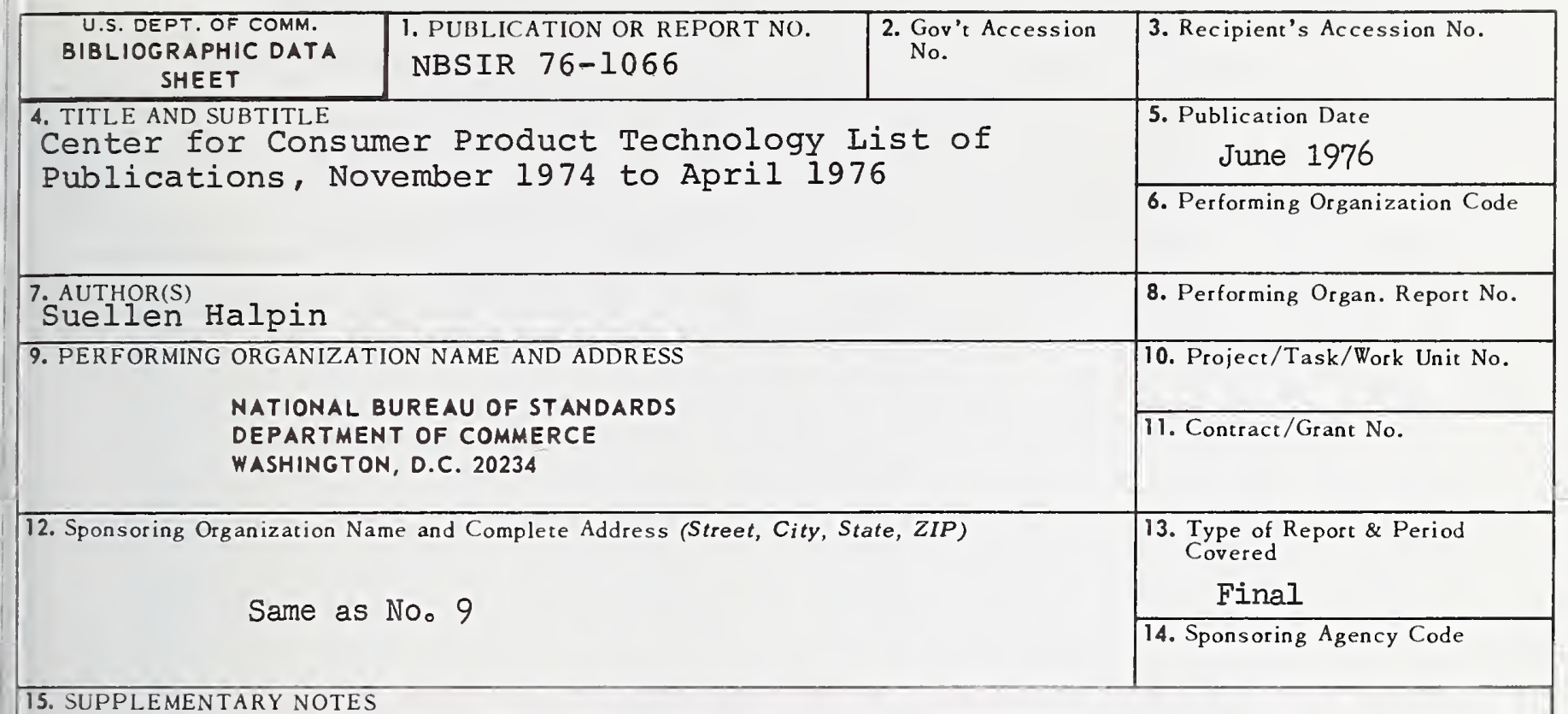

16. ABSTRACT (A 200-word or less factual summary of most significant information. If document includes a significant bibliography or literature survey, mention it here.)

"Center for Consumer Product Technology Publications, November 1974 to April 1976" lists only publications prepared by the members of the Center for Consumer Product Technology staff, by NBS personnel under contract or grant to the Center or by NBS personnel or external laboratories under contract or grant from the Center are cited. Articles published in NBS house publications also are cited.

17. KEY WORDS (six to twelve entries; alphabetical order; capitalize only the first letter of the first key word unless a proper name; separated by semicolons)

Bibliographies; Consumer product technology; Consumer product safety; Consumer product standards; Law enforcement equipment; Law enforcement equipment standards; Product performance; Product safety

\begin{tabular}{|c|c|c|}
\hline $\begin{array}{l}\text { 18. AVAILABILITY } \square \text { Unlimited } \\
\square \text { For Official Distribution. Do Not Release to NTIS }\end{array}$ & $\begin{array}{l}\text { 19. SECURITY CLASS } \\
\text { (THIS REPURT) } \\
\text { UNCL ASSIFIED }\end{array}$ & 21. NO. OF PAGES \\
\hline $\begin{array}{l}\square \text { Order From Sup. of Doc., U.S. Government Printing Office } \\
\text { Washington, D.C. 20402, SD Cat. No.C13 }\end{array}$ & $\begin{array}{l}\text { 20. SECURITY CLASS } \\
\text { (THIS PAGE) }\end{array}$ & 22. Price \\
\hline $\begin{array}{l}\text { X Order From National Technical Information Service (NTIS) } \\
\text { Springfield, Virginia } 22151\end{array}$ & UNCLASSIFIED & \\
\hline
\end{tabular}



